\title{
Secondary Sex Ratio in Gir Cattle and Assessment of Risk Factors
}

\author{
Suryakant S. Parikh ${ }^{1^{*}}$, Tapas Kumar Patbandha ${ }^{2^{*}}$ and Rinkesh B. Makwana ${ }^{1}$ \\ ${ }^{1}$ Cattle Breeding Farm, Junagadh Agricultural University, Junagadh, Gujarat, INDIA \\ ${ }^{2}$ Veterinary College, Junagadh Agricultural University, Junagadh, Gujarat, INDIA \\ *Corresponding authors: SS Parikh; E-mail:drss.parikh@gmail.com
}

Received: 18 Dec., 2020

Revised: 18 Jan., 2021

Accepted: 23 Jan., 2021

\begin{abstract}
Present study was conducted to assess the influence of calf, dam and sire factors on female calves born in Gir cattle. Records pertaining to calf sex $(n=1307)$, spreaded over 10 years (2010-2019) and various calf factors viz. period, month, season and sex of calf; dam factors viz. age, parity and gestation period and sire factors were used for the study. Female calf born in Gir cattle was $49.96 \%$. Calf sex was not affected by period of birth $(p=0.26)$, but significantly higher proportion of female birth than male $(60.22 \%$ vs. $39.78 \%)$ occurred in $2013(p<0.05)$. Odds of female calf being born was 1.75 times higher in 2013 as compared to $2010(\mathrm{OR}=1.75, p=0.04)$. Month $(p=0.31)$ and season $(p=0.41)$ of birth did not affect calf sex. There was significantly higher chances of female birth during February $(\mathrm{OR}=1.66, p=0.05)$ and March $(\mathrm{OR}=1.67, p=0.04)$ as compared to January. Calf sex was not affected by age $(p=0.44)$ and parity $(p=0.85)$ of dam. With increase in gestation length the birth frequency of female calf decreased significantly $(p<0.001)$. Compared to gestation period of $>290$ days, the odds of female calf born increased by $2.25(\mathrm{OR}=2.25, p=0.001)$ and $2.27(\mathrm{OR}=2.27, p=0.001)$ times with gestation period of $<275$ and 275-290 days, respectively. Sire wise data showed that proportion of female birth ranged from 22 to $90 \%$, but female calf born from different sires did not differ statistically $(p=0.13)$. Chances of female birth was significantly higher $(\mathrm{OR}=3.79-31.5, p<0.05)$ in 12 sires. The results indicated that gestational length had significant effect on secondary calf sex ratio in Gir cattle and dam with shorter gestation period delivered more number of female calves.
\end{abstract}

\section{HIGHLIGHTS}

(0) Gestational length had significant effect on proportion of female calf born in Gir cattle.

(0) There was significantly higher probabilities of female birth during February and March as compared to January.

Keywords: Secondary sex ratio, Gir cattle, Female calf, Risk factors

Gir cattle is one of the important milch breeds of India spotted in South Saurashtra Agro-climatic zone of Gujarat having 2810 and $2573 \mathrm{~kg}$ lactation and standard lactation milk yield, respectively (Patbandha et al., 2020). This region housed different types of domestic animals as well as wild animals. This region has 0.98 and 1.70 million breedable cattle and buffalo population, respectively $\left(20^{\text {th }}\right.$ livestock census, 2020). Female birth is more essential for dairy herd as compared to the male counterpart as the former is kept for herd replacement (Yilmaz et al., 2010; Sawa et al., 2014). Furthermore, financial attraction of dairy farmers is more when the replacement rates are better (Berry and Cromie, 2007). In current scenario, determination of secondary sex ratio i.e. either male to female or female to male live births of calves is having keen interest of many researchers. Various factors have been reported by the earlier workers with variation in expected 50:50 sex ratio in dairy animals (Kaygisiz and Vanli, 2008; Yilmaz et al., 2010; Berry et al., 2011; Sawa et al., 2014; Khan et al., 2013). Sex ratio can be manipulated by enhancing the selection and genetic improvement programmes (Seidel, 2003). As per the sex ratio allocation

How to cite this article: Parikh, S.S., Patbandha, T.K. and Makwana, R.B. (2021). Secondary sex ratio in Gir cattle and assessment of risk factors. J. Anim. Res., 11(1): 199-205.

Source of Support: None; Conflict of Interest: None (क) ब 
theory of Trivers and Willard (1973), mothers in better physiological conditions would give birth to male calves. Reproductive success varies more among one sex than the other. Factors responsible for difference in the secondary sex ratio might be due to the classification of breed, age of dam and sire, season, parity, year, herd size, body condition score and the levels of sex hormones (Singh et al., 2004; Roche et al., 2006; Yilmaz et al., 2010). There is paucity of reports on secondary sex ratio in indigenous breed like Gir. Hence, this study was planned to identify the factors and determine the association of relationship between the odds of female births in zebu cattle under tropical to subtropical climate of Gujarat.

\section{MATERIALS AND METHODS}

\section{Study area and data collection}

Data pertaining to the present experiment were collected from records of Gir cattle (Bos indicus) maintained at Cattle Breeding Farm, Junagadh (Gujarat), India. The farm is located at $70.5^{\circ}$ west longitude, $21.4^{\circ}$ north latitude and an altitude of 60 meters above mean sea level. Tropical to sub-tropical climate prevails in the study area. Animals were maintained under loose housing system with pucca floor, fed seasonal green fodder (maize, jowar and berseem) @ $10 \mathrm{~kg} / \mathrm{cow}, a d$-lib dry fodder and measured amount of concentrate mixture to meet the nutritional requirement as per Indian Council of Agricultural Research (ICAR, 2013) feeding standards. Health monitoring protocols were followed as per routine farm standards. Artificial insemination programme was followed using semen from proven bulls evaluated under All India Co-ordinate Research Project (AICRP). Information of calves (date of birth, sex and weight), dam (age, parity, gestation period) and sire (sire number/ name) were collected from the records of 10 years period (from 2010 to 2019). In the study, records of normal full term birth $(n=1307)$ comprised of insemination from 28 sires were included.

\section{Classification of data and statistical analysis}

Factors affecting secondary sex ratio (female to male calf) in Gir cattle were first grouped into different classes using certain criteria. Total 10 year study period was first divided into 10 classes based on date of birth $\left(\mathrm{P}_{1}: 2010\right.$,
$\mathrm{P}_{2}: 2011, \mathrm{P}_{3}: 2012, \mathrm{P}_{4}: 2013, \mathrm{P}_{5}: 2014, \mathrm{P}_{6}: 2015, \mathrm{P}_{7}: 2016$, $\mathrm{P}_{8}: 2017, \mathrm{P}_{9}: 2018$ and $\left.\mathrm{P}_{10}: 2019\right)$. According to months data were categorized into 12 classes (January through December) and seasons into 3 classes (Winter: NovemberFebruary, Summer: March-June and Rainy: July-October). Considering previous calf sex, data were classified into 2 groups such as female and male calves. Data were further classified based on dams' age into 5 classes ( $\leq 4$ years, 5-6 years, 7-8 years, 9-10 years and $>10$ years); dams parity into 8 classes $\left(1^{\text {st }}, 2^{\text {nd }}, 3^{\text {rd }}, 4^{\text {th }}, 5^{\text {th }}, 6^{\text {th }}, 7^{\text {th }}\right.$ and $\left.\geq 8^{\text {th }}\right)$; dams' gestation period into 3 classes $(<275$ days, 275-290 days and $>290$ days) and service sire into 28 classes (1-28). Effect of period of birth, month of birth, season of birth, previous calf sex, dams' age, dams' parity, dams' gestation period and service sire on proportion of female calves was analysed by chi-square test. Considering the probability of 0.5 (or $50 \%$ ) a calf being born either female or male, the observed and expected frequencies were also compared by chi-square test. Further the association of risk factors with odds of female calf being born was estimated by binary logistic regression where the birth of a female calf was coded as ' 1 ' and birth of male calf as ' 0 '. Results were considered as significant when ' $p$ ' $\leq 0.05$ and a 'trend' if ' $p$ ' $\leq 0.1$ but $>0.05$. All the statistical analyses were carried out using SPSS software version 16.

\section{RESULTS AND DISCUSSION}

\section{Secondary sex ratio}

The overall female calf born during 10 years of study period (from 2010 to 2019) in Gir cattle was 49.96\%, which did not deviate from the hypothesized probability of calf sex as 0.5 or $50 \%$ (Table 1 ). The secondary sex ratio in Gir cattle is in agreement with Hossein-Zadeh (2012) who found the overall ratio of females to males was 50.4: 49.6 in Holstein cattle. Delesa et al. (2014) studied the calves' sex ratio in naturally and artificially bred cattle and stated that AI did not alter the female to male ratio in dairy cattle. Contrary to the present study, Sawa et al. (2014) and Del Rio et al. (2007) observed female to male ratio as 47.21: 52.79 and 53.3: 46.7, respectively in HF dairy cows. The differed expected ratio was also observed by Goshu and Singh (2013) in HF cattle and Banik and Naskar (2006) in Sahiwal cattle. Several factors viz. vaginal and uterine $\mathrm{pH}$, 
maturity of the oocyte, timing of AI and climatic factors at AI also affect secondary sex ratio (Pursley et al., 1998).

\section{Effect of calf factors on female calf born}

\section{Period of calving}

Period of birth did not affect calf sex $\left(\chi^{2}=11.18, \mathrm{df}=9\right.$, $p=0.26$ ), but significantly higher proportion of female birth (60.22\% vs. 39.78\%) occurred during 2013 as compared to male calf $\left(\chi^{2}=3.88, \mathrm{df}=1, p<0.05\right.$; Table 1$)$. Proportion of female calves born increased from 2010 to 2013, from 2014 to 2016 and from 2017 to 2019. Similarly, Sawa et al. (2014) found number of female calves increased every year during the analyzed period (45.53\% in 2000-2001 to $52.12 \%$ in 2012). Roche et al. (2006) and Kaygisiz and Vanli (2008) found non-significant effect of calving year on secondary sex ratio. A skewed sex ratio from year to year and its dependent on year also observed by Yilmaz et al. (2010). Contrary to Gir cattle, earlier researchers found a significant relationship between the year of calving and sex ratio of calves (Lathwal and Kumar 1994; Berry and Cromie, 2007 and Goshu and Singh, 2013). Roche et al. (2006) and Kaygisiz and Vanli (2008) found nonsignificant effect of calving year on secondary sex ratio. The variation in female calves born in different season might be due to the large differences in climate within season.

Table 1: Period wise proportion of female calves (\%) born in Gir cattle $(\mathrm{n}=1307)$

\begin{tabular}{llll}
\hline $\begin{array}{l}\text { Period/ Year of } \\
\text { birth }\end{array}$ & Total & $\begin{array}{l}\text { No. of } \\
\text { females }\end{array}$ & $\begin{array}{l}\text { Female } \\
(\mathbf{\%})\end{array}$ \\
\hline 2010 & 123 & 57 & 46.34 \\
2011 & 107 & 54 & 50.47 \\
2012 & 117 & 63 & 53.85 \\
2013 & 93 & 56 & $60.22 *$ \\
2014 & 156 & 69 & 44.23 \\
2015 & 132 & 62 & 46.97 \\
2016 & 178 & 99 & 55.62 \\
2017 & 155 & 71 & 45.81 \\
2018 & 110 & 54 & 49.09 \\
2019 & 136 & 68 & 50.00 \\
\hline Total & $\mathbf{1 3 0 7}$ & $\mathbf{6 5 3}$ & $\mathbf{4 9 . 9 6}$ \\
\hline$\chi 2=11.18, \mathrm{df}=9, p=0.264 ; *=$ Significant at $5 \%(p<0.05)$. \\
\hline
\end{tabular}

Considering calving year 2010 as reference, the odds of female calf being born was $75 \%$ higher in 2013 (OR=1.75, $p=0.04$; Table 7). Hossein-Zadeh (2012) studied the period effect on odds of male births in Iranian Holsteins and observed higher male to female ratio (52.5:47.5) during 1996-1999 which decreased during 2004-2007 i.e. 48.5: 51.5 . The odds of male birth was 1.18 in 20042007 as compared to 1996-1999 and 1.01 in 2004-2007 as compared to 2000-2003, which reflected decrease in male to female sex ratio in recent years (Hossein-Zadeh, 2012). Although there was significant effect of year of birth on probability of female calf but there is no clear and conclusive reason (Berry and Cromie, 2007).

\section{Month and season of calving}

Month $\left(\chi^{2}=12.73, \mathrm{df}=11, p=0.31\right)$ and season $\left(\chi^{2}=\right.$ $1.76, \mathrm{df}=2, p=0.41)$ of birth did not affect the calf sex in Gir cattle (Table $2 \& 3$ ). Calf sex also did not differ from the expected probability of $50 \%$ in any month or season. Proportion of female calves born was higher in rainy season $(52.39 \%)$ followed by summer $(49.77 \%)$ and winter season (47.91\%), respectively. Singh et al. (2004) stated that calving season has slight effect on sex ratio of the calves born. Uniform female calves born in individual calving season was observed by Sawa et al. (2014), whereas, other researchers did not observe any relationship between season and sex ratio of calve (Mukherjee et al., 2000; Kaygisiz and Vanli, 2008; Goshu and Singh, 2013).

Table 2: Month wise proportion of female calves (\%) born in Gir cattle $(n=1307)$

\begin{tabular}{llll}
\hline Month of birth & Total & No. of females & Female (\%) \\
\hline Jan & 133 & 58 & 43.61 \\
Feb & 103 & 58 & 56.31 \\
Mar & 117 & 66 & 56.41 \\
Apr & 113 & 55 & 48.67 \\
May & 113 & 56 & 49.56 \\
Jun & 91 & 39 & 42.86 \\
Jul & 78 & 34 & 43.59 \\
Aug & 110 & 61 & 55.45 \\
Sep & 109 & 59 & 54.13 \\
Oct & 121 & 65 & 53.72 \\
Nov & 87 & 41 & 47.13 \\
Dec & 132 & 61 & 46.21 \\
\hline$\chi 2=12.73, \mathrm{df}=11, p=0.311$ & &
\end{tabular}


Table 3: Season and previous calf wise proportion of female calves (\%) born in Gir cattle

\begin{tabular}{|c|c|c|c|}
\hline Parameters & Total & $\begin{array}{l}\text { No. of } \\
\text { females }\end{array}$ & $\begin{array}{l}\text { Female } \\
(\%)\end{array}$ \\
\hline \multicolumn{4}{|c|}{ Season of birth $(n=1307)$} \\
\hline Winter & 455 & 218 & 47.91 \\
\hline Summer & 434 & 216 & 49.77 \\
\hline Rainy & 418 & 219 & 52.39 \\
\hline \multicolumn{4}{|c|}{$\chi^{2}=1.76, \mathrm{df}=2, p=0.415$} \\
\hline \multicolumn{4}{|c|}{ Previous calf $\operatorname{sex}(n=860)$} \\
\hline Female calf & 435 & 215 & 49.43 \\
\hline Male calf & 425 & 207 & 48.71 \\
\hline \multicolumn{4}{|c|}{$\chi^{2}=0.04, \mathrm{df}=1, p=0.833$} \\
\hline
\end{tabular}

Although proportion of male calves born increases with increasing air temperature and humidity around the time of conception (Roche et al., 2006), such association was not observed in Gir cattle.

Logistic regression analysis reflected that there was significantly higher chances of female birth during February $(\mathrm{OR}=1.66, p=0.05)$ and March $(\mathrm{OR}=1.67$, $p=0.04$; Table 7) as compared to January. Moreover, a trend of higher female calf being born in the month of August $(\mathrm{OR}=1.61, p=0.06)$ was observed. In Holstein cows, higher proportion of male calves born in spring $(\mathrm{OR}=1.02 ; \mathrm{P}<0.0001)$, and the lowest male calves born in summer or fall calvings as reported by Hossein-Zadeh (2012). Further, Berry and Cromie (2007) reported higher proportion of male birth during warm months (FebruaryJune) as compared to colder months (December-January).

\section{Previous calf sex}

Sex of previous calf did not affect secondary sex ratio in Gir cattle $\left(\chi^{2}=0.04, \mathrm{df}=1, p=0.833\right.$; Table 3$)$. Further, calf sex also did not deviate from the probability of a female calf being born with a chance of 50\%. Although previous studies reported that the sex of the previous calf to the same cow had significant $(p<0.05)$ effect on the sex of the subsequent calf (Roche et al., 2006; Berry and Cromie, 2007; Hossein-Zadeh, 2012), such effect was not observed in Gir cows. The repeatability of calf sex of a particular dam is primarily influenced by the permanent environmental factor of the dam (Hossein-Zadeh, 2012).

\section{Effect of dam factors on female calf born}

\section{Age and parity of dam}

Calf sex was not affected by age $\left(\chi^{2}=3.73, \mathrm{df}=4, p=0.44\right.$; Table 4) and parity $\left(\chi^{2}=3.38, \mathrm{df}=7, p=0.85\right.$; Table 5$)$ of the dam. The sex ratio also did not deviate from the probability of $50 \%$ in any age or parity group. Highest proportion of female calves born in $5^{\text {th }}$ parity $(56.18 \%)$ followed by $1^{\text {st }}$ $(51.24 \%)$ and $2^{\text {nd }}(49.85 \%)$ parity cows. The proportion of female calves born at $1^{\text {st }}$ calving was $48 \%$ followed by $44 \%$ and $51 \%$ in second and fifth-seventh calving, respectively (Goshu and Singh, 2013). The present study favored that the proportion of female calves was higher to primiparous (51.24\%) compared to multiparous (48.65\%) cows. Sawa et al. (2014) and Singh et al. (2004) observed similar results. The probability of male calves born was significantly higher in aged cows as compared to younger cows (Berry and Cromie, 2007). Earlier researchers did not find any significant effect of number of calving on the sex ratio of the calves born (Kaygisiz et al., 2003, Roche et al., 2006) which is supported by present study.

Table 4: Age wise proportion of female calves (\%) born in Gir cattle $(\mathrm{n}=1307)$

\begin{tabular}{llll}
\hline Age of dam & Total & No. of females & Female (\%) \\
\hline$\leq 4 \mathrm{yr}$ & 337 & 171 & 50.74 \\
$5-6 \mathrm{yr}$ & 426 & 211 & 49.53 \\
$7-8 \mathrm{yr}$ & 266 & 139 & 52.26 \\
$9-10 \mathrm{yr}$ & 142 & 61 & 42.96 \\
$>10 \mathrm{yr}$ & 136 & 71 & 52.21 \\
\hline$\chi 2=3.73, \mathrm{df}=4, p=0.443$ & & \\
\hline
\end{tabular}

Table 5: Parity wise proportion of female calves (\%) born in Gir cattle $(\mathrm{n}=1307)$

\begin{tabular}{llll}
\hline Parity of dam & Total & No. of females & Female (\%) \\
\hline 1 & 404 & 207 & 51.24 \\
2 & 331 & 165 & 49.85 \\
3 & 216 & 103 & 47.69 \\
4 & 137 & 67 & 48.91 \\
5 & 89 & 50 & 56.18 \\
6 & 57 & 28 & 49.12 \\
7 & 30 & 12 & 40.00 \\
$\geq 8$ & 43 & 21 & 48.84 \\
\hline$\chi 2=3.38, \mathrm{df}=7, p=0.848$ & &
\end{tabular}




\section{Gestation period of dam}

With increase in gestation length the frequency of female birth decreased significantly $\left(\chi^{2}=21.13, \mathrm{df}=2, p<0.001\right.$; Table 6). Frequency of female birth was significantly lower (32.69\% vs. $67.31 \%)$ as compared to male counter parts in Gir cows with gestation length beyond 290 days $\left(\chi^{2}=18.69, \mathrm{df}=1, p<0.001\right)$. The chances of female calf birth increased by $2.25(\mathrm{OR}=2.25, p=0.001$; Table 7) and $2.27(\mathrm{OR}=2.27, p=0.001$; Table 7$)$ times in case dams having gestation period of $<275$ days and 275-290 days, respectively as compared to those with gestation period of $>290$ days.

Table 6: Gestation period wise proportion of female calves (\%) born in Gir cattle

\begin{tabular}{llll}
\hline $\begin{array}{l}\text { Gestation } \\
\text { period }\end{array}$ & Total & No. of females & Female (\%) \\
\hline$<275$ days & 139 & 73 & 52.52 \\
$275-290$ days & 1012 & 529 & 52.27 \\
$>290$ days & 156 & 51 & $32.69^{*}$ \\
\hline$\chi^{2}=21.13$, df $=2, p<0.001 ; *=$ Significant at $0.1 \%(p<0.001)$. \\
\hline
\end{tabular}

Table 7: Associated risk factors (period of birth, month of birth and gestation period) for female calf in Gir cattle

\begin{tabular}{|c|c|c|c|c|c|}
\hline Parameters & Estimates & SEM & OR & $95 \%$ CI & P value \\
\hline \multicolumn{6}{|l|}{ Period of birth } \\
\hline 2013 vs. 2010 & 0.561 & 0.279 & 1.752 & $1.015-3.025$ & 0.044 \\
\hline \multicolumn{6}{|l|}{ Month of birth } \\
\hline $\begin{array}{l}\text { February vs. } \\
\text { January }\end{array}$ & 0.511 & 0.265 & 1.667 & $0.992-2.800$ & 0.054 \\
\hline $\begin{array}{l}\text { March vs. } \\
\text { January }\end{array}$ & 0.515 & 0.256 & 1.673 & $1.014-2.762$ & 0.044 \\
\hline $\begin{array}{l}\text { August vs. } \\
\text { January }\end{array}$ & 0.476 & 0.260 & 1.610 & $0.968-2.677$ & 0.067 \\
\hline \multicolumn{6}{|l|}{ Gestation period } \\
\hline $\begin{array}{l}<275 \text { days vs. } \\
>290 \text { days }\end{array}$ & 0.823 & 0.241 & 2.277 & $1.420-3.651$ & 0.001 \\
\hline $\begin{array}{l}275-290 \text { days vs. } \\
>290 \text { days }\end{array}$ & 0.813 & 0.182 & 2.255 & $1.579-3.221$ & $<0.001$ \\
\hline
\end{tabular}

There was a scanty report regarding effect of gestation period on calf sex but some information available on calf sex effect on gestation period. Gestation period is affected by several factors viz. calf sex, single or twin pregnancy, age of dam, calving season and genetic factors (Silva et al., 1992). Higher birth weight in male calves might be due to the higher androgen hormone intensity of male fetus serum (Manzi et al., 2012). A significant amount of production of testosterone hormone starts from 45 days of gestation which reaches to peak up to 70 days. During this fetal life, presence of androgen receptors within muscle cells enhances the muscle tissue growth results into weight differences between the sexes (Holland and Odde, 1992). Additional fetal growth in male calves prolongs the gestation period (Rezende et al., 2020). A positive relationship exists between the gestational length and birth weight of calf. Gestation length prolonged by 1.1 (Silva et al., 1992) to 2.0 days (Hayr et al., 2015) in case of male calves.

\section{Effect of sire on female calf born}

\section{Service sire}

Sire wise data showed, proportion of female birth ranged from 22.22 to $90.00 \%$ (Fig. 1 \& Table 8). However, the sex of calf born from different sires did not differ statistically $\left(\chi^{2}=35.24, \mathrm{df}=27, p=0.13\right)$. Moreover, out of 28 sires, the proportion of female birth significantly $(p<0.05)$ deviated from probability of $50 \%$ in 3 sires and the frequency of female calf was $22.22 \%\left(\chi^{2}=5.56, \mathrm{df}=1, p<0.05\right), 70.37 \%$ $\left(\chi^{2}=4.48, \mathrm{df}=1, p<0.05\right)$ and $90.00 \%\left(\chi^{2}=6.40, \mathrm{df}=1\right.$, $p<0.05)$. Variations of secondary sex ratio in HF dairy sires have been documented in earlier studies (Berry et al., 2011; Hossein-Zadeh, 2012).

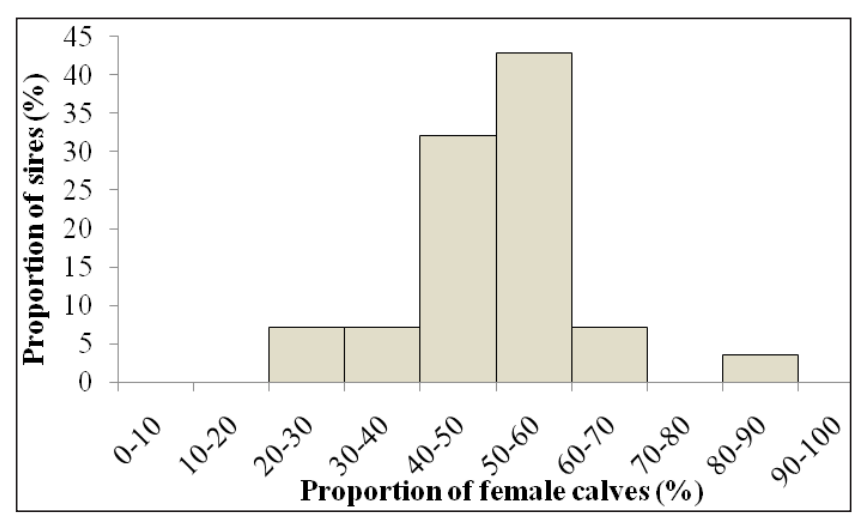

Fig. 1: Histogram of female Gir calves (\%) and service sires (\%)

The variation might be due to the relatively small number of sires represented in most of the studies. The ejaculation 
Table 8: Associated sire factor for female calf in Gir cattle

\begin{tabular}{lllll}
\hline Percent of female calves & Estimates \pm SEM & OR & 95\% CI & P value \\
\hline Reference sire- $22.22 \%$ female calves & $-1.253 \pm 0.567$ & 0.286 & - & 0.027 \\
44.04 & $1.013 \pm 0.599$ & 2.754 & $0.852-8.907$ & 0.091 \\
45.16 & $1.059 \pm 0.622$ & 2.882 & $0.852-9.749$ & 0.089 \\
45.45 & $1.070 \pm 0.628$ & 2.917 & $0.851-9.993$ & 0.088 \\
45.78 & $1.084 \pm 0.608$ & 2.956 & $0.897-9.736$ & 0.075 \\
46.15 & $1.099 \pm 0.632$ & 3.000 & $0.870-10.343$ & 0.082 \\
47.06 & $1.135 \pm 0.663$ & 3.111 & $0.848-11.408$ & 0.087 \\
47.62 & $1.157 \pm 0.608$ & 3.182 & $0.967-10.468$ & 0.057 \\
50.00 & $1.253 \pm 0.737$ & 3.500 & $0.825-14.848$ & 0.089 \\
50.00 & $1.253 \pm 0.737$ & 3.500 & $0.825-14.848$ & 0.089 \\
50.00 & $1.253 \pm 0.642$ & 3.500 & $0.994-12.321$ & 0.051 \\
52.00 & $1.333 \pm 0.634$ & 3.792 & $1.095-13.129$ & 0.035 \\
52.22 & $1.342 \pm 0.605$ & 3.826 & $1.169-12.521$ & 0.027 \\
52.38 & $1.348 \pm 0.646$ & 3.850 & $1.086-13.647$ & 0.037 \\
52.63 & $1.358 \pm 0.653$ & 3.889 & $1.080-13.997$ & 0.038 \\
52.94 & $1.371 \pm 0.633$ & 3.938 & $1.140-13.604$ & 0.030 \\
56.02 & $1.495 \pm 0.588$ & 4.459 & $1.408-14.120$ & 0.011 \\
56.67 & $1.521 \pm 0.676$ & 4.577 & $1.216-17.223$ & 0.024 \\
57.78 & $1.566 \pm 0.642$ & 4.789 & $1.360-16.865$ & 0.015 \\
59.09 & $1.620 \pm 0.714$ & 5.056 & $1.248-20.480$ & 0.023 \\
70.00 & $2.100 \pm 0.748$ & 8.167 & $1.885-35.380$ & 0.005 \\
70.37 & $2.118 \pm 0.706$ & 8.313 & $2.082-33.194$ & 0.003 \\
90.00 & $3.450 \pm 1.197$ & 31.500 & $3.017-328.930$ & 0.004
\end{tabular}

of an unequal ratio of $\mathrm{X}$ and Y-bearing sperm, differences in capacitation and fertilization rate, differences among sexes in the rate of intrauterine attrition at different stages of development from zygote to the fetus might be the possible reasons of variable sex ratio (Berry et al., 2011). Logistic regression analysis of sire data showed wide variation of female calf being born from different sires considering the lower frequency of female calf born from the sire $(22.22 \%$ female calf) as reference. The chances of female calf birth increased significantly $(\mathrm{OR}=3.79-31.5$, $p<0.05)$ in 12 sires and there was a trend of higher odds of female birth in 10 sires $(\mathrm{OR}=2.7-3.5, p<0.1)$.

\section{CONCLUSION}

The proportion of female Gir calves born was not affected by period, month, season of birth and age or parity of dam. In Gir cows, there was no significant effect of previous calf sex on secondary sex ratio. Gestational length had significant effect on proportion of female calf born in Gir cattle. The frequency of female birth was found significantly lower as compared to male counter parts in Gir cows with gestation length beyond 290 days. Sire wise data suggested the proportion of female birth ranged from 22.22 to $90.00 \%$.

\section{ACKNOWLEDGEMENTS}

The authors express their sincere gratitude to Research Scientist and Head, Cattle Breeding Farm, Junagadh Agricultural University, Junagadh for providing facilities under which the present experiment was carried out.

\section{REFERENCES}

Banik, S. and Naskar, S. 2006. Effect of different non-genetic factors on replacement rate and its components in Sahiwal cattle. Indian J. Anim. Sci., 76(4): 343-45. 
Berry, D.P. and Cromie, A.R. 2007. Artificial insemination increases the probability of a male calf in dairy and beef cattle. Theriogenology, 67(2): 346-352.

Berry, D.P., Kearney, J.F. and Roche, J.R. 2011. Evidence of genetic and maternal effects on secondary sex ratio in cattle. Theriogenology, 75(6): 1039-1044.

Del Rio, N.S., Stewart, S., Rapnicki, P., Chang, Y.M. and Fricke, P.M. 2007. An observational analysis of twin births, calf sex ratio, and calf mortality in Holstein dairy cattle. J. Dairy Sci., 90(3): 1255-1264.

Delesa, E.K., Yohannes, A., Alemayehu, M., Samuel, T. and Yehualaeshet, T. 2014. Calves' sex ratio in naturally and artificially bred cattle in central Ethiopia. Theriogenology, 82(3): 433-439.

Goshu, G. and Singh, H. 2013. Genetic and non-genetic parameters of replacement rate component traits in Holstein Friesian cattle. Springer Plus, 2(1): 581.

Hayr, M.K., Hess, A.S. and Garrick, D.J. 2015. Impact of including calf gender in models to predict breeding values for lactation yields in dairy cattle. Anim. Industry Report, 661(1): $1-2$.

Holland, M.D. and Odde, K.G. 1992. Factors affecting calf birth weight: a review. Theriogenology, 38(5): 769-798.

Hossein-Zadeh, N.G. 2012. Factors affecting secondary sex ratio in Iranian Holsteins. Theriogenology, 77(1): 214-219.

ICAR. 2013. Nutrient requirements of cattle and buffaloes. New Delhi, India: ICAR

Kaygisiz, A. and Vanli, Y. 2008. Factor influencing sex ration in Brown Swiss cattle. Indian J. Anim. Sci., 78(6): 656-657.

Kaygisiz, A., Vanli, Y. and Cakmak, L. 2003. Estimates of genetic and phenotypic parameters of sex ratio in Holstein cattle. In GAP III. Agricultural Congress, Sanliurfa, Turkey.

Khan, F.A., Sacchan, S.S.D., Singh, M.P., Patoo, R.A., Prasad, S. and Gupta, H.P. 2013. Trivers-Willard hypothesis revisited: Does heat stress peri-insemination alter secondary sex ratio in crossbred dairy cattle? Asian Pac. J. Reprod., 2(3): 218219.

Lathwal, S.S. and Kumar, A. 1994. Genetics of replacement rate and its components in Red Sindhi herd. Indian Vet. J., 71(9): 892-896.

Livestock Census. 2020. All India Report. Ministry of Agriculture, Department of Animal Husbandry, Dairying and Fisheries, Krishibhavan, New Delhi, India.
Manzi, M., Junga, J.O., Ebong, C. and Mosi, R.O. 2012. Factors affecting pre and post-weaning growth of six cattle breed groups at Songa Research station in Rwanda. Livest. Res. Rural Dev., 24(4): 68-70.

Mukherjee, K., Tomar, S.S. and Singh, R.B. 2000. Variability in sex ratio in Karan Swiss cattle. Indian J. Anim. Res., 34(1): 24-28.

Patbandha, T.K., Sabapara, G.P., Savaliya, B.D., Dash, S.K., Parikh, S.S. and Ali, M. 2020. Physical characteristics and production performance of Gir cattle in India. Int. J. Livest. Res., 10(8): 1-11.

Pursley, J.R., Silcox, R.W. and Wiltbank, M.C. 1998. Effect of time of artificial insemination on pregnancy rates, calving rates, pregnancy loss and gender ratio after synchronization of ovulation in lactating dairy cows. J. Dairy Sci., 81(8): 2139-2144.

Rezende, E.V., Reis, I.J., Campos, C.C. and Santos, R.M. 2020. Influence of gestation length, seasonality, and calf sex on birth weight and placental retention in crossbred dairy cows. Cienc. Anim. Brasileira, 21.

Roche, J.R., Lee, J.M. and Berry, D.P. 2006. Climatic factors and secondary sex ratio in dairy cows. J. Dairy Sci., 89(8): 3221-3227.

Sawa, A., Jankowska, M. and Glowska, M. 2014. Effect of some factors on sex of the calf born, and of sex of the calf on performance of dairy cows. Acta Sci. Pol. Zootech., 13(3): $75-84$.

Seidel, G.E. 2003. Economics of selecting for sex: the most important genetic trait. Theriogenology, 59(2): 585-598.

Silva, H.M., Wilcox, C.J., Thatcher, W.W., Becker, R.B. and Morse, D. 1992. Factors affecting days open, gestation length, and calving interval in Florida dairy cattle. J. Dairy Sci., 75(1): 288-293.

Singh, B., Kumar, D., Singh, H., Prasad, R.B. and Singh, J.B. 2004. Genetic studies on sex ratio in dairy cattle. Indian $J$. Anim. Sci., 74(9): 986-988.

Trivers, R.L. and Willard, D.E. 1973. Natural selection of parental ability to vary the sex ratio of offspring. Science, 179(4068): 90-92.

Yilmaz, I., Eyduran, E. and Kaygisiz, A. 2010. Determination of some environmental factors related to sex ratio of Brown Swiss calves. J. Anim. Plant Sci., 20(3): 164-169. 
